\title{
Terrorism and Religion in Indonesia: a Comparative Study of the Two Literary Works
}

\author{
Sukron Kamil \\ Faculty of Literature and Humanities \\ Syarif Hidayatullah State Islamic University Jakarta \\ Indonesia \\ sukronkamil@uinjkt.ac.id
}

\begin{abstract}
Terrorist often mentioned as Islamic terrorism is influenced more likely by the views and feelings of social injustice, both nationally and globally. Islamic religious understanding, that does not show true Islam, is used by the perpetrators and the 'brains' behind terrorism in the period of the Reform in Indonesia to legitimize its acts of terrorism. More precisely, it is the religious understanding of jihadist salafi/jihadist fundamentalism sourced from Islamic ideology such as Sayyid Qutb and Abdullah Azzam. Both (social injustice and salafi jihadist), in this research, are the two undivided and not mutually exclusive currencies, because if they are not united it is difficult to bear terrorism. Therefore, countering terrorism or deradicalization should not only be a military and legal approach, but also must involve many institutions, political, economic, psychological, and social institutions such as education and religion. This conclusion was derived from the study of comparative literature of American School on two Indonesian literary works, a novel and a memoir, reinforced by confessions of the terrorist perpetrators of the first Bali bombing, especially Imam Samudra. The two literary works examined were a realist novel Demi Allah Aku Jadi Teroris (For the Sake of Allah, I Become a Terrorist) by Damien Dematra and a memoir Temanku Teroris? Saat Dua Santri Ngruki Memilih Jalan Berbeda (is my friend terrorist? When Two Students of Ngruki Chose a Different Way), by Noor Huda Ismail. While the confessions of terrorists were derived from the book of Imam Samudra Aku Melawan Teroris (I am Against Terrorists) and other relevant sources. Both were certainly still reconfirmed by the findings of academic works of the experts and the results of in-depth interviews.
\end{abstract}

Keywords- terrorism, social injustice, jihadist salafi, comparative literature, and academic work

\section{INTRODUCTION}

Terrorism is an act of violence to spread panic, widespread intimidation and destruction of vital objects, or to obtain ransom, an act is considered a criminal act but no as a war that makes innocent civilians a target, and often the victims are mass, undertaken by an individual or a subnational group or clandestine agents opposing a state for political objectives or for its own interests [1][2]

The act of terrorism in this sense is now a frequent phenomenon, especially since the last 200 years. Terrorism is not only done by groups in the movement carrying religion but also, both locally and internationally, is mostly done mainly by secular groups [3]. Nevertheless, terrorism, or at least violence in the name of religion, has recently been flaring up. It is not only done by a group of people who are in the name of Islam, but also other religions. In fact, religious terrorism by some experts is now considered a new direction of terrorism [4].

Jewish fundamentalist terrorism, for example, could be seen from the event of 25 February 1994 that killed 63 Palestinian Muslims who were performing the shubuh prayers at Hebron Mosque [5][6][4][7]. Terrorism also belongs to Protestant Christian fundamentalists such as "cult" like David Koresh in America [8][9][10] [11], and Hindu people such as supporters of Bharatiya Janata Party (BJP). The supporters of BJB demanded such as the demolition of the Babri Mosque that stood since 1952, believing that Rama was born from that place. They also committed terror by rioting between the end of 1990- 1991, where more than 1000 people died and 4000 were injured [8][9][10][4][11]. In Buddhism, there is also the same trend as seen in the Aum Shinrikyo group [12]. In terrorism, it seems that there is no single political ideology as well as any single extremist religion that dominates the use of terrorism. Terrorism belongs to many ideologies and religions that are believed to be extreme/exaggerated.

However, the most striking later is terrorism in the name of Islam. Terrorism in the name of Islam continues to grow, although the war against global terrorism has lasted more than 10 years. The attacks of 'Islamic' terrorists also swept the world, from North Africa to Southeast Asia. The target also reaches Casablanca, Madrid, London, Istanbul, Riyadh, Jakarta, and Bali.

The act of terrorism in the name of Islam that was most shocking and receiving the attention of mass media or world was an attack on the World Trade Center building as well as Pentagon Building in the United States on September 11, 2001 and the terrorism of Bali bombing I in Indonesia in 2002 [10].

Up until now Islamic terrorism is still a threat to Indonesia. According to $\mathrm{Al}$ Chaidar, there are about 200 potential terrorists in Indonesia today, although according to Ansyaad Mbai, Head of BNPT (National Agency for Combating Terrorism), there are still 100 likely potential people to be terrorists. Indonesia is a category prone to terrorism. Some literatures, in fact, call Indonesia at emergency of terrorism. From the records of BNPT team, the acts of terrorism that occurred during the Reformation era totaled more than 103 actions. Of that number, $41 \%$ occurred in houses of worship, especially churches and Christian institutions, and $43 \%$ in public places, such as hotels and offices [13][14]. From 
January to July 2001 alone, some books mention 81 actions. Although strong acts of terrorism are relatively new in the history of Indonesia [15].

The act of terrorism in the name of Islam by radical Islamists seems to be categorized by Oliver Roy, a French political scientist, as a "radical neo fundamentalism", or by Roel Meijer as a "salafi global jihadist" [16][17]. In Indonesia, the perpetrators - such as Jamaat Islamiyyah and Mujahidin of West and East Indonesia - are connected with the latent underground movement of NII (Islamic State of Indonesia) [18][19].

Furthermore, the relationship of terrorism and Islam by Western writers is not only related to the partial misinterpretation of the non-mainstream Muslims but with Islam itself as a whole. Sam Harris in his essay in the Washington Times for example states "it is time we acknowledge that we are not fighting against terrorism. We are fighting against Islam. .... Every American should read the Qur'an and see that non-Muslims are smeared mercilessly on its pages". Likewise, Lauwrence Auster from FrontPage magazine also echoes the same sentiment [10].

\section{METHOD}

To obtain comprehensive data and analysis on the topic or focus of analysis, the method used in the research was the source of this paper which combined two main aspects. From the field of science, this research used approaches in literary and religious studies, especially Islamic studies. The literary theory used in this research is the theory of realist literature, especially social realist, and the American comparative literary theory $[20][21][22][23][24][25]$. While the perspective of Islamic studies used is the approach of sociology of religion and sociology of integrative politics to look at the phenomenon of terrorism in the name of Islam.

Therefore, the data collection method used in this research was a qualitative method. In this sense, the research made two literary works as the main object of the study; a novel Demi Allah Aku Jadi Teroris by Damien Dematra and a memoir Temanku Teroris? Saat Dua Santri Ngruki Memilih Jalan Berbeda by Noor Huda Ismail. These two literary texts were quoted, and compared in accordance to the American comparative literary theory with the views and confessions of the perpetrators derived from Imam Samudra's book $A k u$ Melawan Teroris! and confessions of other terrorists derived from various sources, including newspapers. Both were still reconfirmed by the findings of academic works of experts and the results of in-depth interviews.

\section{RESULT AND DISCUSSION}

Based on the research conducted with the above methodology, terrorism often mentioned as Islamic terrorism was influenced more by the views and feelings of social injustice, both nationally and globally. The religious understanding of Islam that did not show the true Islam was used by the actors and the brains behind terrorism in the Reformation period in Indonesia to legitimize their acts of terrorism. More precisely, it is the religious understanding of salafi or jihadist fundamentalism sourced from Islamic ideologists such as Sayyid Qutb [17] and Abdullah Azzam. Both (social injustice and salafi jihadist), in this research, were the two undivided and not mutually exclusive currency, because if they were not united it would be difficult to generate terrorism.

Terrorism is analyzed in this research by using three measures; (1) the use of violence or terror by targeting civilians, although sometimes security forces, high officials, and government agencies are also targeted; (2) launched by non-State actors, although terrorism also covers the state terrorism; and (3) with the aim of obtaining certain political outcomes. It is the measure that distinguishes terrorism by violence from violence itself or harmony for the benefit of illegal money-making [26][15][1].

The meaning of global social justice in this research is the reality of the US occupation and the allies over Afghanistan followed by then on Iraq after the terrorist attacks of September 11, 2001. Previously, the Zionist occupation of Palestine have been supported by the United States since 1940, and the military control of the United States over Saudi Arabia is since the Gulf War of 1990s, in addition to the time when the Gulf War also invaded Iraq by making innocent civilians a target. The US and its allies are considered by terrorists, such as Imam Samudra and, of course, by Osama bin Laden which have occupied three holy mosques: the Grand Mosque in Mecca, the Nabawi Mosque in Madinah (Sudi Arabia), and the Aqsa Mosque in Palestine. The United States and its allies are also claimed to have controll the land of Prophet Muhmmad's revelation and homeland and also Baghdad as the center of Islamic power, the capital of the Abbasid caliphate (8th-13th century AD). The reality of injustice committed by the United States and its allies can be found not only in the confessions of terrorists like Imam Samudra, but also in the novel and the memoir studied.

The US and allies considered by the Bali bombing I terrorists have crossed the limit, as they made the Islamic civil society a target of attack. As a result, thousands of women, children, and other Muslim civilians were killed or disabled for life. It also happened in Afghanistan, Iraq and in Israel through the Zionists. They call the US and allies the Crusaders. Imam Samudra felt that if one died of US citizens and allies, the whole world was busy, as if all the people in the world should be responsible, however, if thousands of Muslims died in their hands, the whole world, including Muslim leaders and also the ulamas, are in silence. Therefore, the terrorism of Bali bombing I considered the perpetrators as jihad to fight or to respond US and allies as they do not violate Muslims and fellow mujahidin (other actors of Islamic terrorism in the world) tortured in barbarian ways at Guantanamo, a notoriously famous prison in the US. Although this topic mentioned in the novel, it can be seen more clearly in the memoir and certainly in the direct confession of the perpetrators of terrorism.

For terrorists, US civil society and allies in everywhere targeted by terrorism are not a problem. The reason, because 
according to them, the US and its allies have made Muslim civil society in several Muslim countries as a target. This is the penalty for the same act. Another reason is that in countries with democratic systems like the US and its allies, the people must be responsible for the actions of their country that do wrong to the Muslim states. The course of power in democracy must involve the people. They must also be responsible, since they have helped the Government attacking the Muslim countries through the taxes. After all, they are considered civilians who control the military, because in the US and allied countries there is a mandate of the military (compulsory military), although in the social studies of terrorism, the army who does not serve only considered civil, let alone ordinary citizens. In the memoir and the novel, this question was not revealed clearly, even in the memoir, a tendency was identified.

The global injustice is a concern and a source for terrorists in Indonesia during the Reformation period. Since they were born, they are influenced by the existence of international relations with world of terrorism, especially al-Qaida leader, Osama bin Laden. This type of terrorism is often called transnational terrorism. In this case, JI (Jamaah Islamiah) was born in 1992 in the hands of Abdullah Sungkar after settling with Ajengan Maduki in Di / TII (Darul Islam of Islamic Army of Indonesia) while in Malaysia it is connected with alQaida. The initial program linking them was war training and war of Afghanistan against the Soviets (Russia) of the late 1980s and early 1990s. They were also formed in relation to the Moro fighters in Mindanao, Southern Philippines, who gave their territory to JI to form the Hudaibiyyah camp, a military training camp. If in the camp, Afganistan gave birth to the perpetrators of terrorism of Bali bombing I (Imam Samudra Amrozi and friends), Then Hudaibiyyah camp in Mindanao gave birth to the perpetrators of terrorism generation like Nurdin M. Top, Dr. Azhari and friends after the death of the Imam Samudra and friends. The second generation of terrorist perpetrators had been destroyed since Nurdin M. Top died in 2009. Now, the dangerous terrorists are MIT (Mujahidin of Indonesia Timur) which is organized by JAT (Jamaah Ansharut Tauhid) and MIB (Mujahidin Indonesia Barat). Both are networked with MIB helping funding MIT and MIT aims to make Poso as the basis for the Islamic state they want to establish. In this memoir, the transnational terrorism was revealed, although the next developmental terrorism was not.

Certainly, also the factor of the birth of terrorism at the period of the Reformation is also the views and feelings of national social injustice. Indonesia is considered by H. Amir, ustadz Kemala, as the main character in the novel, and also Utomo and Ustazd Abu Bakar Ba'asyir in memoirs, as a nonsurviving country. Murder, infanticide, kidnapping, mutilation, corruption, and so on occur in many places. Injustice is everywhere, because Indonesia is led by the New Order as the government of taghout (the government of zalim [syetan]). In the language of Abu Bakar Ba'syir, led by Soeharto has made him the pharaoh of Indonesia. The government of SBY (Susilo Bambang Yudoyono), and even
Joko Widodo at this time, in this sense are also the same, because the Government of SBY was often called as the New Order Part II, even by non-terrorists. The reason, according to $\mathrm{H}$. Amir, is because Indonesia is not based on Islamic law. It is a country based on neo ilyasiq law, a new mixed law from various sources of man-made law that once prevailed in the Eastern Islamic world under Hulagu Khan, the son of Genghis Khan, in the 13th and 14th centuries. Terrorism, therefore, is a political movement, both political resistance to the West as well as opposition to the internal Government, including under President SBY, and also Joko Widodo. In the twoliterary works and the confession of terrorists was also found that the birth of terrorism was also certainly not only a reality seen as a form of national and global social injustice, but also other social issues. Among these wer the factors of friendship and social environment that were accustomed to violence. A factor that also affect was the individual psychology, because they felt alienated like a sense of arrogance and the sense of not wanting to be over controlled by trauma such as rape, as experienced by Kemala, a main character of the novel [27][28][29][30][2][13].

However, the views and feelings of social injustice and other social factors then get legitimized by the mindset and the tendency of Islamic religious sense of salafi (fundamentalism). By taking a partial verse or partial hadith and not referring to the standard interpretation, the religious interpretation of the version of the terrorists legitimize the terrorism acts at last. Among these are the religious views of those who believe all of the ruling regimes in Muslim countries have fallen apart, because they are based on nonShari'ah laws; high officials and regime military or police who do not apply Islamic law are also apostates; considering Muslim communities as infidels who live under the pagan regime., Although this view is for several terrorists only; labelling ulama as infidels who brand the jihadist movement as disoriented; and who believe in democracy, secularism, and nationalism are pagan political ideologies. In this sense, the ideological Islamic concepts affect them [27][28].

They are influenced primarily by the views of Sayyid Qutb, an Egyptian political and fundamentalist ideolog, in the book Ma'alim Fiat-Thariq (Signs Towards Straight Path). The main idea of this book is the declaration of absolute power of Allah (al-hakimiyyah) through the doctrine of la hukma illa lillah (no law except the law of God) as a nature of His ongoing reign. According to Qutb, today, Muslim society is in a state of ignorance as before Islam existed, even the level of modern ignorance, both in Egypt and in the West, is worse. Including the category of Jahiliyyah is also partly what has been considered Islam, because it has been mixed with nonMuslims, especially Greek and Christian. For Qutb, ignorance is not a time period, i.e. pre-Islamic period. This is a recurring situation whenever society diverges from the path of Islam, whether in the past, the present, or the future. Any attempt to deny the sovereignty of God through his laws is jahili. Nationalism (which makes the state an entity and the highest value), communism (the atheist), and democracy (where people rob God's power) are all embodiments of ignorance. 
It's all about worshiping humanity, not God. Also included in jahiliyah is pragmatism (Western cultural reasons which hold that anything, if not beneficial to many, should be avoided) as well as materialism.

The main task of a Muslim is to change the reality of Jahiliyyah to return to Islam and all Muslims should become a congregation (a group of loyal individuals who swear to fulfill God's laws and seek to substitute all forms of ignorance). Qutb also conceived that jihad is not in the sense of defense, as Sunni does generally, but in offense, that is the proclamation of the liberation of man from slavery other than to God. The offensive jihad also means fighting any group that rejects the true implementation of Islamic norms agreed upon. In addition, Sayyid Qutb also interpreted the word yahkum in QS 5: 44,45,46, not by "deciding" but "commanding" not by the law revealed by Allah as a kafir act. Although Qutb did not explicitly advocate attacks against the Nasir government, but his arguments provided the basis for the radical Islamic organization after the Sadat period to do so. His view was then a counter-project against the modernization projects undertaken by the Nasir regime and later in Egypt, even in other Islamic worlds [31][32][33][34][7].

In addition to the above doctrines, which also legitimize terrorism, also the concept of qishash (penalty) in Islam is used to avoid war; the concept of modern ignorance (where the system of law and human thought is counted as God's rival); and the concept of jihad that is no longer understood as war in the sense of defense, but also offense. They, in this last question, follow Umar's statement that "the best defense as is the offense", which is in fact irrelevant, as it used to be pronounced by Umar during the war situation between the Muslims and the Romans, not at the time of peace as of now [19].

Given the factors that give birth to terrorism, then the countermeasures of terrorism/deradicalization must also not only be military and legal approaches. This approach is certainly important as implemented by the US, UK, and Sri Lanka. However, this approach can be judged to violate human rights and can be ineffective, since the effect on humans is on the heart and mind. Therefore, what must be done is also reeducation by providing a counterterrorism religious understanding (Islam rahmatan lilalamin or social welfare as the core of Islam); teaching a rational religious behavior; breaking up terrorists with the terrorist social environment that shelters them; technical engagement (rule of engagement); economic training for terrorists to live a normal life; resocialization by treating terrorists and their families with a humanist attitude, not stigmatized; and creating a world where genuine equality and mutual respect are upheld by all, including in the developed countries. However, it must be ensured that there is no short-term solution to the problem of terrorism. In the long run, counterterrorism should be as a policy that prohibits member recruitment from the beginning [27][28][35][2][13].

\section{CONCLUSION}

Recently, terrorism often cited by Islamic terrorism is more influenced by the views and feelings of social injustice, both nationally and globally. These unfair views and feelings are then legitimized by a religious understanding of Islam that does not really represent the true Islam. More precisely is the religious understanding of salafi or jihadist fundamentalism. Social injustice and jihadist salafi are the two undivided and not mutually exclusive currency. Therefore, countermeasures of terrorism or deradicalisation should not only be one approach such as military or law enforcement alone.

The research findings are in line with Imam Feisal Abdul Rauf's view; while in the United States, with the views of Karen Armstrong, and Bilveer Singh. The findings of this research differ from the experts who see terrorism as a matter of social injustice (terrorism as opposed to social injustice, both local and global) such as Sukawarsini Djelantik, Erik S. Case, and Robert A. Pape. The findings of this research also differ from those who see terrorism as a religious issue such as Charles Kimbal, Roel Meijer and Thomas Heggamer. Lasltly, the findings stand in different end with the view that Islamic terrorism is a matter of Islam in general as claimed by SamHarris [36].

\section{REFERENCE}

[1] A. Kuper and J. Kuper, Ensiklopedi Ilmu-Ilmu Sosial, vol. II, Jakarta: Rajawali Pres, 2000.

[2] F. Purwawidada, Jaringan Teroris Solo, Jakarta: Kepustakaan Populer Gramedia, 2014.

[3] B. Setiawan, Ensiklopedi Nasional Indonesia, vol. 16, Jakarta: Cipta Adi Pustaka, 2004.

[4] A. Hendropriyono, Terorisme Fundamentalis Kristen, Yahudi, dan Islam, Jakarta: Kompas, 2009.

[5] A. Shihab, Islam Inklusif Menuju Sikap Terbuka dalam Beragama, Bandung: Mizan, 1998.

[6] E. Turmudi and R. Sihbudi, Islam dan Radikalisme di Indonesia, Jakarta: LIPI, 2005.

[7] K. Amstrong, Berperang Demi Tuhan, Fundamentalisme dalam Islam, Kristen, dan Yahudi, Bandung: Mizan, 2013.

[8] I. Adams, Ideologi Politik Mutakhir, Konsep, Ragam, Kritik, dan Masa Depannya, Yogyakarta: Qalam, 2004.

[9] R. Karyono, Fundamentalisme dalam Kristen dan Islam, Yogyakarta: Klika, 2003.

[10] J. L. Esposito and D. Mogahed, Saatnya Muslim Bicara, Bandung: Mizan, 2008.

[11] C. Kimbal, Kala Agama Jadi Bencana, Bandung: Mizan, 2013.

[12] I. F. A. Rauf, Seruan Azan dari Puing WTC: Dakwah Islam di Jantung Amerika Pasca 9/11, Bandung: Mizan, 2007.

[13] A. Surya Bakti, Darurat Terorisme, Kebijakan, Pencegahan, Perlindungan dan Deradikalisasi, Jakarta: Daulat Press, 2014.

[14] A. Ndupa, Strategi Penanggulangan Terorisme di Indonesia. [Online]. Available: http://news.liputan 6.com.

[15] S. Djelantik, Terorisme: Tinjauan Psiko-Politis, Peran Media, Kemiskinan dan Keamanan Nasional, Jakarta: Yayasan Obor, 2010.

[16] O. Roy, The Failure of Political Islam, Massachussett: Harvard University, 1994.

[17] R. Meijer, Ed., Global Salafism: Islam New Religious Movement, London: C. Hurst \& Co, 2009.

[18] Mataharitimoer, Jihad Terlarang, Cerita dari Bawah Tanah: Kisah 
Nyata Mantan Aktivis Islam Garis Keras, Jakarta: Kayla Pustaka, 2007.

[19] S. Kamil, Islam dan Politik di Indonesia Terkini, Jakarta: PSIA UIN Jakarta, 2013.

[20] M. Arif Rokhman, "Pendahuluan: Dari Monodisipliner Menuju Interdisipliner," in Sastra Interdisipliner, Menyandingkan Karya Sastra dan Disiplin Ilmu Sosial, Yogyakarta, Qalam, 2003, p. 2.

[21] S. Djoko Damono, Sastra Bandingan, Pengantar Ringkas, Jakarta: Editum, 2009.

[22] N. Raghib, at-Tafsir al-'Ilmi li al-Adab, Nahw Nazhariyyah 'Arabiyyah Jadidah, Kairo: as-Syirkah al'Alamiyyah li an-Nasyr, 1998.

[23] H. Remak, "Sastra Bandingan, takrif dan Definisi," in Sastra Perbandingan, Kaidah dan Perspektif, N. P. Stallknecht and H. Frenz, Eds., Kualalumpur, Dewan Bahasa dan Pustaka, 1990.

[24] T. Nada, al-Adab al-Muqaran, Kairo: Dar al-ma'arif, 1998.

[25] R. Wellek and W. Austin, Teori Kesusastraan, Jakarta: Gramedia, 1995.

[26] E. S. Case, "Terorisme," in Ilmu Politik dalam Paradigma, Jakarta, Kencana Prenada Media Grup, 2013, p. 201.

[27] I. Noor Huda, Temanku Teroris? Saat Dua Santri Nruki Memilih Jalan Berbeda, Jakarta: Hikmah, 2010.
[28] K. Amstrong, "Pengantar," in Seruan Azan dari Puing WTC: Dakwah Islam di Jantung Amerika Pasca 9/11, Bandung, Mizan, 2007, p. xviii.

[29] A. Mbai, Dinamika Baru Jejaring Teror di Indonesia, Jakarta: AS Production Indonesia, 2014.

[30] D. Sagiv, Islam Otentisitas Liberalisme, Yogyakarta: LKiS, 1997.

[31] H. Mushthafa, al-Islam as-Siyasi Fi Mishra, Kairo: Maktabah al-Usrah, 2005.

[32] J. L. Esposito, Ensiklopedi Oxford Dunia Islam, vol. 5, Bandung: Mizan, 2001.

[33] R. D. Lee, Mencari Islam Autentik, Bandung : Mizan, 2000.

[34] D. Dematra, Demi Allah Aku Jadi Teroris, Jakarta: Gramedia, 2009.

[35] M. Keliat, "Jalan Panjang Menuju Negara Modern," in Auman Terakhir Macan Tamil: Perang Sipil Sri Lanka, Jakarta, Kompas, 2010, pp. xxixxiii.

[36] R. A. Pape, Dying to Win: The Strategic Logic of Suicide Terrorism, New York: Random House, 2005. 